\title{
Relationship Analysis of Demography Characteristics on Female Workers' Income of Couturier Business in Banda Aceh
}

\author{
Fanny Nailufar ${ }^{1}$ and Sufitrayati ${ }^{2}$ \\ \{fannynailufar24@gmail.com\} \\ ${ }^{1}$ Department of Economic Development, Universitas Malikussaleh, Aceh Indonesia \\ ${ }^{2}$ Department of Accounting, Universitas Serambi Mekkah, Aceh Indonesia
}

\begin{abstract}
This research was conducted to answer the problems in the field of entrepreneurship especially couturier business, so it can be the concept of increasing the income of female workers in the couturier business. Data analysis in this research was done by using analysis model of Cross Tabulations (Crosstabs) by using Chi-Square $\left(\mathrm{X}^{2}\right)$ test. Based on the result of research, it indicated that there was a significant correlation between monthly incomes with age of female workers. The chi-square test $\left(\mathrm{X}^{2}\right)$ also showed that there was no significant relationship between monthly income and the formal level of female workers. Meanwhile, a significant relationship was shown between monthly income and marital status of female workers. The result of testing using chisquare test also showed that there is a relationship between monthly income and the number of dependents of female workers' family
\end{abstract}

Keywords: Demography, Female Workers, Couturier

\section{Introduction}

Indonesian women with the number more than half the population of Indonesia, is a potential human resources in development. However, the potential of women that is relatively large has not been utilized, especially in productive activities. The productive activities here is what is commonly called as working or doing an activity or assisting in doing some activities in order to earn income or revenue. Women, in their own decision, being participated in the labour market not only influenced by marital status but it is also influenced by demographic characteristics of age, residence (city/village), income, religion, education level, number of family dependents, husband's income level (for those already married), the women's education themselves as well as the regional unemployment rate. The main problem of female workers is the low social background which requires women to work.

In addition, the increased participation of the female labour in the labour market does not occur by chance. The increase in the percentage of working women is caused by two main factors, namely the increase in supply and demand sides [1]. In terms of supply, it is caused by the improvement of the level of education of women and it is also caused by the decline in the number of births. It is also encouraged by the increasing social acceptance of women who are working outside the house. From the demand side, economic development (from the 
production side) requires female labour such as in textile and garment industries. While other phenomenon that increasingly encourage the entry of women to the workplace is due to the high cost of living if it is only supported by one family income buffer (One Earner Household). This phenomenon has emerged and has been clearly visible especially in families in urban areas.

According to data from the Central Bureau of Statistics (BPS) Banda Aceh, the number of women including the labour (female population aged over 15 years and for those who worked) is quite large, 14,682 people. The results of SUPAS (Intercensal Population Survey) 2015 shows that the number of women who have not/never attended school is 105 people, while the number of women who do not/have not finished elementary school is 171 people. Meanwhile, the number of women who graduated from elementary school is 833 people which is lower than the number of women who graduated from junior high school, 1,397 people. However, the number of woman labour in Banda Aceh who graduated from senior high school is 6,330 people, it is bigger than those who graduated from university, 5,821 people.

Increased Women's Labour Force Participation Rate is also affected by changes in the education level of the workforce, whereas the female work force of elementary and junior secondary education has lower participation rates than well-educated women or undergraduates. The development of science and technology has helped women to run various business in accordance with the skills they have. The current business of many women is couturier business. By opening this business, it will expand employment and business opportunities and it will improve the prosperity of artisans through the increase of revenue.

Couturier business is one of the handicraft businesses that has prospect in the future and it is a business done at leisure time, whether it is done outside or at home with the aim to increase family income, so that the business is increasing day by day. Along with the time, the need for clothing is not just to cover the body, but it has other functions such as for beauty, and aesthetics. The need for clothing is also increasing because of many activities outside the house. So the emergence of couturier business aims to meet the needs of people's clothes.

\section{Theoretical Review}

\subsection{Demographic Characteristics}

\subsubsection{Age Factor}

According to Sumarsono, the behaviour of the workforce is varied based on age group [2]. The publications of the Central Bureau of Statistics (BPS) divide the group into classes with 5-year interval classes into three age groups:

$\begin{array}{ll}\text { Young } & \text { aged } 10-24 \text { years } \\ \text { Excellent } & \text { aged } 25-60 \text { years } \\ \text { Old } & \text { aged over } 60 \text { years old }\end{array}$

The youth labour force is usually unstable and its association with the labour market is still not strong. At this age, there is still another alternative in their time allocation of school. While the labour force group of excellent age is usually at this age that a person must work because of the demands of family responsibilities or because already invest their time to work then they are required to be active in the labour market. Meanwhile, for the age of 60 years old and over, for some people, is the period of resignation from the labour market where the level 
of health is still low so that at the age, they are less able to be active in the labour market physically.

\subsubsection{Education Level}

In general the type and level of education is considered to represent the quality of labour. Education is a process that aims to increase skills, knowledge and increase independence and the formation of a person's personality. The things that are attached to the person is the basic capital needed to carry out the work. The higher asset values leads to a better ability in working. Their productivity is supported by education. Thus education can be used as an indicator of labour quality [2]. The level of education in Indonesia used by the Central Bureau of Statistics (BPS) is:

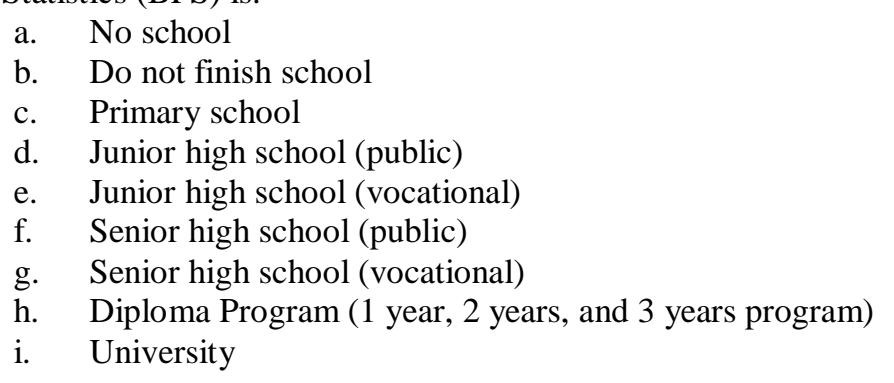

2. Number of Family Dependent

3. Marital Status

\subsection{Wages and Salaries}

One of the major forms of labour welfare is wages. Wages are essentially all remuneration or remuneration given by the enterprise to workers for services or work performed in a working relationship. The wages include direct financial rewards such as basic wages or salaries, allowances, incentives and indirect financial rewards such as social security, facilities, or non-financial rewards such as challenging jobs and career opportunities. Therefore, it is clear that wages are a very important aspect of employment.

According to the Council for Wage Research, wages constitute acceptance as a reward from the granting of labour to the acceptance of work for a work or service which has been and will be performed which serves as a guarantee of viable survival for humanity and production that is expressed or valued in terms of money set by a agreements, laws and regulations and are paid on the basis of an employment agreement between the employer and the recipient.

In Government Regulation No. 14 of 1993 defining wages are as follows: "Wages constitute as an acceptance in return for the employer to the worker for a work or service which he has or will do, declared or assessed in the form of money stipulated in accordance with a process of purpose or legislation and paid on the basis of an employment agreement between the employer and the labourer, including benefits for both the workers themselves and for their families ".

The Work Accident Law of 1992 Number 3 defines that wages as payments in the form of money received by workers in exchange for employment. Meanwhile, according to Poerwono 
[3], wages are the total amount set as a substitute for services that have been issued by the worker covering a certain period or conditions.

Wages or salaries can be viewed as rewards or remuneration to workers of the output produced. This reward or service, on one hand, is a right to be earned by workers, but on the other hand is an incentive to increase productivity [1].

\subsection{Wage System}

The theory underlying the wage system can be basically distinguished according to two extremes. The first extreme is based on Karl Marx's teachings on theory of value and class disagreement. According to Karl Marx, he states that only labour is a source of economic value. The value of an item depends on the value of the labour service or the amount of working time used to produce the goods. The second extreme is based on the theory of the addition of marginal products (Neo Classics) which is based on the assumptions of the free economy. Classical Neo Theory suggests that in order to maximize the profits of each entrepreneur using the factors of production in such a way that each factor of production used to receive or be rewarded by the value of the increase of marginal results of the factors of production. The employer employs a number of employees in such a way that the value of one's marginal return is equal to the wage that the person receives. The wage system in various countries including Indonesia is generally between the two extremes.

The basis of the remuneration system in Indonesia is the Constitution, Article 27, paragraph (2). The wage system in Indonesia is generally based on three wage functions [4]:

1. Being able to guarantee a decent life for workers and their families.

2. Reflecting rewards for one's work.

3. Providing incentives that can encourage increased work productivity and national income.

Earnings or remuneration received by an employee or worker in respect of his work may be classified into the following forms:

1. Wages and salaries in the form of money.

2. Allowances in kind.

3. Fringe benefits (additional allowances).

4. The condition of work environment.

Wages are basically the main source of one's income, therefore wages should adequately meet the needs of the workers and their families appropriately. This feasibility can be assessed and measured with Minimum Living Needs (KHM).

\subsection{Couturier Business}

The Directorate of Vocational Secondary Education of the Department of Education and Culture states: "Couturier is a sewing business done by individuals and is an side-line job". Wancik [5] mentions: "Couturier is a model expert and a dressmaker for women (where women's clothes are sewed)".

From the above statement, the current couturier develops not like the old couturier, just as a side-line job. But today's couturier is a model master and a tailor of women who make her couturier business as the main job or a place to earn a living and increase family income. Today couturier business is also managed by many women to utilize the skills they have to add experience as well as increase family income. 
Business is an activity that can produce quality goods and carried out continuously, meaning the activities of holding goods or services or facilities for sale with the aim of obtaining optimal benefits. According to Sutjiono [6], "Business is a work done in succession according to certain rules or rules to achieve goals".

The current couturier business is developed as a source of income, with the current economic situation making couturier busines must be able to develop themselves by improving the skills and creativity of the workers. Couturier business today is not as a sideline work done by mothers and young women in their spare time, but couturier business as one source of income that is able to meet the needs of families and able to hire other people who have skills as labour to earn income.

\subsection{Terms of a Couturier Business}

According to the Directorate of Vocational Secondary Education of the Ministry of Education and Culture: "In a couturier business all work ranging from organizing, cutting up to completion is done on its own. Usually with simple equipment and assisted by 2 or 3 employees only ".

From the above explanation it can be understood that the couturier business develops its business by using simple equipment and assisted by its employees. Nowadays couturier business has developed in accordance with technological developments, couturier business today using more modern equipment. Couturier Business must have employees because the couturier business terms is in completing orders assisted by employees and the more advanced a couturier business can be marked by the increase of employees and equipment needed for order completion

\subsection{Workforce}

The labour concept used in Indonesia is in accordance with the concept suggested by the ILO (International Labour Organization), which is to divide the population into two groups: working age and non-working age population. The working age population is divided into two groups based on ongoing activities, namely the labour force and not the workforce. In Indonesia, generally, the meaning of labour is the population aged 15-64 years. According to the Central Bureau of Statistics (BPS), workers are residents aged 10 years and above.

The workforce is everyone who belongs to the working group in accordance with the relevant state labour law [7]. Meanwhile, according to Suroto [8], the labour force is part of the population in working age who have jobs and who do not have a job but effectively or passively find a job.

The workforce is the number of working population and job seekers [4].

Provision of TK $=$ Workforce $=$ Supply TK

Labour Force $=$ Working + Unemployment

According Sumarsono [2], the workforce is part of the workforce who really want to work to produce goods and services. In Indonesia the workforce is a population aged 10 years and over who really want to work. Those who are willing to work consist of those who actually work and those who do not work but are looking for work.

\subsection{The Job Market}

The job market is a process whereby the occurrence of placement / employment relationship through the supply and demand of labour. Someone in the job market means he is 
offering his services for production, either in a job or looking for a job. Furthermore, the magnitude of labour demand and supply are influenced by the wage rate.

According Sumarsono [2], the labour market is all the activity of the behaviour of actors that bring together job seekers and job vacancies. These actors consist of: (1) Employers who need labour; (2) Job seekers; (3) Intermediaries or third parties that make it easy for employers and job seekers to connect with each other. The intermediary function can be done by government agencies (Labour Department) or consultants

\subsection{Job Opportunity}

Job opportunities describe the size of the household company's willingness to employ the labour required in the production process. The magnitude of this willingness can be measured by the number of people or the number of hours [9].

Job opportunities according to Esmara [10] can be defined as the number of working people or people who have already got a job. The more people working the bigger job opportunities are. The job opportunities are also a condition in which a resident can undertake activities to get service or income for a certain period [11].

Meanwhile Prayitno [12] defines job opportunities as a place for a workforce that gets a rewarding job. The job opportunities can also be defined as positions that are generated both inside and outside the company as a result of investment and population growth and workforce on the one hand and the rate of investment growth on the other hand will affect the problem of unemployment and expansion of job opportunities [13].

\section{METHODS}

The research was conducted in Banda Aceh City which is the Capital of Aceh Province. This research discussed about female labour in Banda Aceh City. The discussion of this study was limited to the problem of the influence of demographic characteristics on female workers' income. The workers, in this case, are female worker who have worked in the industrial sector of couturier business in Banda Aceh City.

The research was conducted quantitatively with descriptive research design. Descriptive design aims to explain something, such as: explaining the characteristics of a relevant group, estimating the percentage of a core in a particular population that exhibits certain behaviours, knowing the perception of product characteristics, knowing how much a variable is related to and for knowing specific predictions [14]. In this research, the researchers wanted to analyse the relationship between demographic characteristics variable on female workers' income.

The type of data used were primary data and secondary data. The primary data was obtained through interviewing the respondents who are female workers and using a list of questions that have been prepared previously. The secondary data was obtained from indirect sources. This secondary data was obtained from the Central Bureau of Statistics (BPS) of Aceh, the Social Service and Labour of Banda Aceh City, the Office of Labour and Mobility of Aceh Province and various libraries that can assist in discussing the existing problems.

Respondents in this study were female labour force who work as an employee in the couturier business in Banda Aceh City. The number of respondents taken as sample was 50 respondents from 50 couturier business located in Banda Aceh City. The subjects chosen purposively (purposive sampling) with the following criteria:

1. The couturier business that has 2 or 3 employees 
2. Can produce a minimum of 5 pairs of stitches within 1 week

3. Have a customer who remains at least 20 customers.

In analysing the data for this research, the researcher used Crosstabulations (Crosstabs) analysis model using Chi-Square test $\left(\mathrm{X}^{2}\right)$ [15]:

$$
x_{n}^{2}=\sum_{i=1}^{n}\left(\frac{X_{i}-\mu}{\sigma}\right)^{2}
$$

\section{RESULTS AND DISCUSSION}

Banda Aceh is the capital of Aceh province. After tsunami in 2004, Banda Aceh city has an area of $61.36 \mathrm{~km} 2$ with a population of 259,913 people and population density 4,641 per person / Km. In addition, the existing administrative system of government has nine subdistricts consisting of 20 urban villages and 69 villages. Its geographical location lies between 05300 - 05350 North Latitude (LU) and 95300 - 99160 East Longitude (BT).

Banda Aceh City is the Central Government of Aceh Province. The situation of the population and labour in this city is not much different from other cities in Indonesia. But this city has its own distinctive characteristics, especially women, where women must wear Muslim headscarf and clothing, except non-Muslims. Population is the basic capital of development and also one of the problems that get attention from government especially poverty eradication program.

Banda Aceh city has borders on the east by Regency of Aceh Besar, the west is bordered by Indonesian Ocean, Regency of Aceh Besar in the south, and Malaka Strait in the north. While other socio-economic conditions owned by the people of Banda Aceh City together with other cities outside of Banda Aceh.

\subsection{Analysis of Results Crosstabulations Income per Month with Age}

From the research result, it was found that monthly income was less than Rp.1.000.000.with age less than 25 years old for 4 people $(8,0 \%)$, while monthly income was above Rp.2.000.000, - with level age above 45 years as many as 9 people (18.0\%). Using chi-square test (X2) shows that there was a significant correlation between monthly earnings with the age of female labour in Kota Banda Aceh, which was marked by probability value $0,001<\alpha(0,05)$ and also based on spearman correlation amounting to 53.30 percent. For more details, it can be seen in Table 1 below.

Table 1. The Relationship of Monthly Income and Age of Female Workers in Banda Aceh 2017

\begin{tabular}{|c|c|c|c|c|c|c|c|c|c|c|c|}
\hline \multirow{3}{*}{ No } & \multirow{3}{*}{ Monthly Income } & \multicolumn{8}{|c|}{ Age } & \multirow{2}{*}{\multicolumn{2}{|c|}{ Total }} \\
\hline & & \multicolumn{2}{|c|}{$<25$} & \multicolumn{2}{|c|}{$25-35$} & \multicolumn{2}{|c|}{$36-45$} & \multicolumn{2}{|c|}{$>45$} & & \\
\hline & & $\mathrm{N}$ & $\%$ & $\mathrm{~N}$ & $\%$ & $\mathrm{~N}$ & $\%$ & $\mathrm{~N}$ & $\%$ & $\mathrm{~N}$ & $\%$ \\
\hline 1 & < Rp.1.000.000 & 4 & 8,0 & 3 & 6,0 & 1 & 2,0 & 1 & 2,0 & 9 & 18,0 \\
\hline 2 & $\begin{array}{l}\text { Rp.1.000.000- } \\
\text { Rp.2.000.000 }\end{array}$ & 1 & 2,0 & 10 & 20,0 & 4 & 8,0 & 1 & 2,0 & 16 & 32,0 \\
\hline 3 & > Rp. 2.000.000,- & 0 & 0,0 & 6 & 12,0 & 10 & 20,0 & 9 & 18,0 & 25 & 50,0 \\
\hline \multicolumn{2}{|c|}{ Total } & 5 & 10,0 & 19 & 38,0 & 15 & 30,0 & 11 & 22,0 & 50 & 100,0 \\
\hline \multicolumn{2}{|c|}{$P=0,001$} & & & \multicolumn{2}{|c|}{$\mathrm{df}=6$} & & & & & & \\
\hline
\end{tabular}


Spearman Correlation $=0,533$

\subsection{Analysis Crosstabulations Income per Month with Level of Education}

The results showed that monthly income of less than Rp.1,000,000.- with primary school education level of only 1 person (2.0\%), while monthly income of above Rp.2.000.000, - with the level graduate education as many as 10 people (20.0\%). Using chi-square test (X2) showed that there was no significant correlation between monthly income and formal education level of female labour in Banda Aceh, which was marked with probability value $0,492>\alpha(0,05)$ and also based on acquisition spearman correlation value of 24.30 percent. For more details, it can be seen in Table 2 below.

Table 2. The Relationship of Monthly Income and Level of Education of Female Workers in Banda Aceh 2017

\begin{tabular}{|c|c|c|c|c|c|c|c|c|c|c|c|}
\hline \multirow{3}{*}{ No } & \multirow{3}{*}{ Monthly Income } & \multicolumn{8}{|c|}{ Formal Education } & & \multirow[b]{2}{*}{ Total } \\
\hline & & \multicolumn{2}{|c|}{$\begin{array}{l}\text { Elementary } \\
\text { School }\end{array}$} & \multicolumn{2}{|c|}{$\begin{array}{l}\text { Junior } \\
\text { High } \\
\text { School }\end{array}$} & \multicolumn{2}{|c|}{$\begin{array}{l}\text { Senior } \\
\text { High } \\
\text { School }\end{array}$} & \multicolumn{2}{|c|}{ Bachelor } & & \\
\hline & & $\mathbf{N}$ & $\%$ & $\mathbf{N}$ & $\%$ & $\mathbf{N}$ & $\%$ & $\mathbf{N}$ & $\%$ & $\mathbf{N}$ & $\%$ \\
\hline 1 & $<$ Rp. 100.000 & 1 & 2,0 & 0 & 0,0 & 7 & 14,0 & 1 & 2,0 & 9 & 18,0 \\
\hline 2 & $\begin{array}{l}\text { Rp.1.000.000- } \\
\text { Rp.2.000.000 }\end{array}$ & 1 & 2,0 & 1 & 2,0 & 8 & 16,0 & 6 & 12,0 & 16 & 32,0 \\
\hline 3 & $\begin{array}{c}>\text { Rp. } 2.000 .000,- \\
\text { Total }\end{array}$ & $\begin{array}{l}0 \\
2\end{array}$ & $\begin{array}{l}0,0 \\
4,0\end{array}$ & $\begin{array}{l}1 \\
2\end{array}$ & $\begin{array}{l}2,0 \\
4,0\end{array}$ & $\begin{array}{l}14 \\
29\end{array}$ & $\begin{array}{l}28,0 \\
58,0\end{array}$ & $\begin{array}{l}10 \\
17\end{array}$ & $\begin{array}{l}20,0 \\
34,0\end{array}$ & $\begin{array}{l}25 \\
50\end{array}$ & $\begin{array}{l}50,0 \\
100,0\end{array}$ \\
\hline & $\begin{array}{l}\mathrm{P}=0,493 \\
\text { Spearman Correlation }=0,\end{array}$ & & & & $=6$ & & & & & & \\
\hline
\end{tabular}

\section{Results Analysis Crosstabulations Income per Month with Marital Status}

The results showed that monthly income was less than Rp.1.000.000.- with married status of 7 people (14.0\%), while monthly income was above Rp.2.000.000, - with married marriage status as many as 19 people (38.0\%). Using chi-square test (X2) shows that there was a significant correlation between monthly income and marital status of female labour in Banda Aceh, which is marked by probability value $0.000<\alpha(0,05)$ and also based on spearman value correlation of 52.30 percent. For more details, it can be seen in Table 3 below:

Table 3. The Relationship of Monthly Income and Marital Status of Female Workers in Banda Aceh 2017

\begin{tabular}{|c|c|c|c|c|c|c|c|c|}
\hline \multirow{3}{*}{ No } & \multirow{3}{*}{ Monthly Income } & \multicolumn{4}{|c|}{ Marital Status } & \multirow{2}{*}{\multicolumn{3}{|c|}{ Total }} \\
\hline & & \multicolumn{2}{|r|}{ Single } & \multicolumn{2}{|c|}{ Married } & & & \\
\hline & & $\mathbf{N}$ & $\%$ & $\mathbf{N}$ & $\%$ & & $\mathbf{N}$ & $\%$ \\
\hline 1 & $<$ Rp.1.000.000 & 7 & 14,0 & 2 & 4,0 & & 9 & 18,0 \\
\hline 2 & Rp.1.000.000-Rp.2.000.000 & 3 & 26,0 & 3 & 6,0 & 6 & & 32,0 \\
\hline \multirow[t]{2}{*}{3} & > Rp. 2.000.000,- & 6 & 12,0 & 19 & 38,0 & 5 & & 50,0 \\
\hline & $\begin{array}{l}\text { Total } \\
\text { (001 Correlation }=0,523\end{array}$ & 6 & 52,0 & $\begin{array}{c}24 \\
\mathrm{df}=6\end{array}$ & 48,0 & 0 & & 100,0 \\
\hline
\end{tabular}




\subsection{Results Analysis Crosstabulations Income per Month with Number of Family}

Based on the results of research conducted that the income earned per month was below Rp.1.000.000.- with female workers who do not have family dependents of 5 people (10.0\%), while monthly income of over Rp.2.000. 000, - with the number of dependents above 6 people as many as 8 people $(16.0 \%)$. Using a chi-square test (X2) shows that there was a significant relationship between monthly income and the number of dependents of female labour families in Banda Aceh, which was marked by probability value $0.000<\alpha(0,05)$ and also based on value spearman correlation of 67.80 percent. For more details, see Table 4 below.

Table 4. The Relationship of Monthly Income and Number of Family Dependent of Female Workers in Banda Aceh 2017

\begin{tabular}{|c|c|c|c|c|c|c|c|c|c|c|c|}
\hline \multirow{3}{*}{ No } & \multirow{3}{*}{ Monthly Income } & \multicolumn{6}{|c|}{ Number of Family Dependent } & \multirow{2}{*}{\multicolumn{2}{|c|}{$>6$}} & \multirow{2}{*}{\multicolumn{2}{|c|}{ Total }} \\
\hline & & \multicolumn{2}{|c|}{$\begin{array}{l}\text { No Family } \\
\text { Dependent }\end{array}$} & \multicolumn{2}{|c|}{1 - 3} & \multicolumn{2}{|c|}{$4-6$} & & & & \\
\hline & & $\mathbf{N}$ & $\%$ & $\mathbf{N}$ & $\%$ & $\mathbf{N}$ & $\%$ & $\mathbf{N}$ & $\%$ & $\mathbf{N}$ & $\%$ \\
\hline 1 & $<$ Rp. 1.000 .000 & 5 & 10,0 & 3 & 6,0 & 1 & 2,0 & 0 & 0,0 & 9 & 18,0 \\
\hline 2 & $\begin{array}{l}\text { Rp.1.000.000- } \\
\text { Rp.2.000.000 }\end{array}$ & 4 & 8,0 & 8 & 16,0 & 4 & 8,0 & 0 & 0,0 & 16 & 32,0 \\
\hline 3 & > Rp. 2.000.000,- & 0 & 0,0 & 5 & 10,0 & 12 & 24,0 & 8 & 16,0 & 25 & 50,0 \\
\hline & $\begin{array}{l}\text { Total } \\
P=0,001 \\
\text { Spearman Correlation }=0\end{array}$ & 33 & 18,0 & 16 & $\begin{aligned} & 32,0 \\
= & 6\end{aligned}$ & 17 & 34,0 & 8 & 16,0 & 50 & 100,0 \\
\hline
\end{tabular}

\section{CONCLUSION and SUGGESTION}

\subsection{Conclusion}

The test result using chi-square test (X2) showed that there was a significant relationship between monthly payment with the age of female workers in Banda Aceh City, which was marked with probability value $0,001<\alpha(0,05)$ and also based on the acquisition of spearman correlation value of 53.30 percent.

Testing using chi-square test (X2) showed that there was no significant relationship between monthly income and formal education level of female workers in Banda Aceh City, which was marked with probability value $0,492>\alpha(0,05)$ and also based on the acquisition of spearman correlation value of 24.30 percent.

Using a chi-square test (X2) showed that there was a significant relationship between monthly income and marital status of female workers in Kota Banda Aceh, which was indicated by the acquisition of probability $0.000<\alpha(0,05)$ and also based on the acquisition spearman correlation value of 52.30 percent.

Based on the test results using chi-square test (X2) showed that there was a significant relationship between monthly income and the number of dependents of female workers' family in Banda Aceh City, which was marked with probability value $0.000<\alpha(0,05)$ and also based on the acquisition of spearman correlation value of 67.80 percent. 


\subsection{Suggestion}

From the results of the study, it indicates that only the variable level of education is not significantly related to the monthly income of female worker in Banda Aceh which means that the average female workforce has the same level of income despite varying levels of education. Therefore, it is expected to the relevant institutions to pay more attention to the workers' income system in order to prevent social inequality

It is expected that the Local Government of Banda Aceh City will be more empowering and developing the potentials and skills of female workers. It aims to further improve the living standards of the people of Banda Aceh City in particular and Aceh province in general.

We hope you find the information in this template useful in the preparation of your submission.

\section{References}

[1] P. Tjiptoherianto, Human Resources In National Development. Fakultas Ekonomi Universitas Indonesia, 2006.

[2] S. Sumarsono, Ekonomi manajemen sumberdaya manusia dan ketenagakerjaan. Yogyakarta: Graha Ilmu, 2008.

[3] H. Poerwono, "Manajemen Personalia.” Universitas Gadjah Mada, Yogyakarta, 2014.

[4] S. Payaman, "Pengantar Ekonomi Sumber Daya Manusia," Jakarta: LP3ES, 2008.

[5] M. Wancik, Bina Busana. Jakarta: Gramedia Pustaka Utama, 2009.

[6] Sutjiono, Kamus Tata Laksana Produksi dan Pemasaran. Jakarta: Bina Ilmu, 2007.

[7] M. S. P. Hasibuan, Ekonomi pembangunan dan perekonomian Indonesia. Bandung: Armico, 2007.

[8] Suroto, Strategi Pembangunan dan Perencanaan Kesempatan Kerja. Yogyakarta: Gadjah Mada University Press, 2012.

[9] Sudarsono, Pengantar ekonomi mikro. Jakarta: LP3ES, 2016.

[10] S. Esmara, Sumber Daya Manusia, Kesempatan Kerja dan Pembangunan Ekonomi. Jakarta: UI Press, 2015.

[11] S. Sagir, "Sumber Daya Manusia, Kesempatan Kerja dan Pembangunan Ekonomi." Lembaga Penerbit Fakultas Ekonomi Indonesia. Jakarta, 2012.

[12] H. Prayitno and B. Santosa, Ekonomi Pembangunan. Jakarta: Ghalia Indonesia, 2012.

[13] S. Djojohadikusumo, Perkembangan pemikiran ekonomi. Jakarta: Yayasan Obor Indonesia, 2015.

[14] Malhotra, Metode Penelitian. Jakarta: Ghalia Indonesia, 2007.

[15] J. Supranto, "Statistik Teori dan Aplikasi.” Erlangga, Jakarta, 2001. 